\title{
Hanging basket oyster farming: assessing effects on seagrass using aerial photography
}

\author{
Richard Bulmer ${ }^{1, *}$, Shane Kelly ${ }^{2}$, Andrew G. Jeffs ${ }^{1}$ \\ ${ }^{1}$ Leigh Marine Laboratory, University of Auckland, PO Box 349, Warkworth 0941, New Zealand \\ ${ }^{2}$ Coast and Catchment Ltd, PO Box 193, Clevedon 2248, Auckland, New Zealand
}

\begin{abstract}
Hanging baskets are rapidly being adopted in many parts of the world to grow shellfish, especially oysters. The adoption of this method is opening up new areas for aquaculture development. However, expansion into areas that have previously been unusable has been controversial, due to concerns about farms being established in areas with particularly high ecological values and sensitivity. This study investigated the impact of establishing a hanging basket oyster farm in the Kaipara Harbour in northern New Zealand on seagrass. Aerial photographs were analysed with a geographical imaging software in combination with field sampling to detect potential impacts. The hanging basket oyster farm technology was found to have no significant overall impact on seagrass beneath the farm. However, field sampling found a narrow band directly beneath the oyster farm growout lines of less than $5 \%$ of the farm area that had lower seagrass densities and abundance compared to adjacent control zones sampled within the farm. This area was obscured in aerial photographs by farm structures. This highly localised impact is likely due to shading or scour caused by farm structures. Overall, the results indicate that hanging basket technology for shellfish aquaculture has minimal environmental impact on underlying seagrass, representing an improvement over traditional culture technologies. Furthermore, the results confirm that remote sensing methods are useful tools for examining aquaculture impacts on seagrass communities, but only when combined with field sampling.
\end{abstract}

KEY WORDS: Shellfish aquaculture - Hanging basket · Aerial photography · Seagrass · Zostera muelleri · New Zealand

\section{INTRODUCTION}

The recent development of plastic hanging basket technology for the aquaculture of oysters is rapidly replacing more traditional techniques, such as rack and rail technology, which is widely used in many oyster-growing regions of the world, including France, Australia and New Zealand. Rack and rail technology usually consists of a pair of parallel wooden rails suspended in the intertidal zone by posts driven into the seabed at regular intervals, usually in shallow and sheltered areas of the coast. The racks are laid across the rails, and most often consist of wooden or plastic sticks on which the cultivated oysters are attached. The racks can also be used to support large mesh trays or flat bags of loose oysters, especially where single-seed oysters from a hatchery are cultivated. In contrast, the hanging basket technology consists of horizontal wires stretched between posts driven into the seabed; a series of small mesh baskets containing oysters are suspended from the wires. One of the advantages of this farming method is that it allows oyster aquaculture in deeper, more exposed areas, often further from the shore, that were previously unavailable for this activity using the rack and rail aquaculture technology.

There are a number of studies that indicate that oyster aquaculture can impact the marine environment by modifying the water quality, water clarity, and the suspended and benthic sediments (reviewed by Forrest et al. 2009). This may be the result of a combination of factors, such as physical structures 
affecting the flushing capacity of an area, accumulation of shell litter, debris, and associated organisms, biodeposition, contamination, physical disturbance, and shading (Forrest et al. 2009). Of some interest is the impact of oyster aquaculture on benthic seagrass habitats, which are widely regarded as ecologically important habitats in shallow coastal waters (Costanza et al. 1997, Turner \& Schwarz 2006).

Seagrass beds are generally associated with high primary production, supporting numerous detritusbased and herbivore-based food weds, trapping and stabilising bottom sediments, nutrient cycling between the benthic sediment and the water column, as well as providing physical refugia for many mobile organisms (Turner \& Schwarz 2006). Subtidal seagrass is an important nursery habitat for a variety of species (Nagelkerken et al. 2001, Cocheret de la Morinière et al. 2002), including snapper Chrysophrys auratus, which is one of New Zealand's most important commercial and recreational fisheries species. The loss of seagrass beds has been implicated in a decline in the environmental carrying capacity for snapper over the past $100 \mathrm{yr}$ (Morrison et al. 2009).

The morphology of the seagrass Zostera muelleri is highly variable, with leaves varying in length and width throughout its natural range in New Zealand. Zostera muelleri has narrow, translucent leaves with a blunt leaf tip; the leaves have distinct longitudinal veins with cross veins at right angles to the longitudinal veins. The root and rhizome system of this species is extensive and usually buried $<15-20 \mathrm{~cm}$ below the sediment surface. This extensive basal structure allows the plant to rapidly expand through vegetative growth and to regrow quickly from the basal structure if the leaves are removed or smothered (Turner \& Schwarz 2006).

In New Zealand Zostera muelleri is perennial, and spring and summer are typically a time when light supply is high, associated with the accumulation of carbon reserves (Collier et al. 2009) and growth in this seagrass (Turner \& Schwarz 2006). Winter is typically a time when light supply is reduced, which may result in seagrass patches contracting depending on the severity and duration of light limitation (Longstaff \& Dennison 1999). Seagrass has been shown to respond to light limitation by increasing chlorophyll (chl) $a$ and $b$ contents, increasing photosynthetic efficiency, and reducing biomass, shoot density and growth (Abal et al. 1994, Czerny \& Dunton 1995, Longstaff 2003, Bité et al. 2007).

The growth, survival and depth to which seagrass can grow is determined by a combination of factors, such as light availability, nutrients, sediment charac- teristics, temperature, water movement, and tidal regime and associated exposure periods (Turner \& Schwarz 2006). Traditional rack and rail technology in oyster aquaculture has been found to have significant impacts on seagrass beds in studies conducted in the USA and Australia. It has been suggested that this is primarily due to shading or scouring (Everett et al. 1995, Madigan et al. 2000). There is some initial evidence that the impacts on seagrass from hanging basket aquaculture technology may be less than for rack and rail production methods (Madigan et al. 2000, Crawford et al. 2003). Hanging basket technology has been found to result in $68 \%$ less shading than rack and rail production methods (Madigan et al. 2000), and dense beds of seagrass have been observed growing under hanging basket technology (Crawford et al. 2003). The development of a hanging basket oyster farm over areas of subtidal seagrass Zostera muelleri in the Kaipara Harbour in northern New Zealand provided an opportunity to examine the potential impacts of this new aquaculture technology on seagrass.

A number of studies have successfully assessed variation in the spatial extent of mapped beds of seagrass in relation to coastal activities or environmental changes (Young \& Kirkman 1975, Kendrick et al. 2002, Zharikov et al. 2005, Lathrop et al. 2006, Orth et al. 2006). It is possible to assess the variation in the spatial extent of mapped beds of seagrass in relation to the hanging basket oyster farm in the Kaipara Harbour because aerial photographs were taken of the site for $3 \mathrm{yr}$ before and $2 \mathrm{yr}$ after the development of the oyster farm in 2008. A potential drawback of using aerial photographs to assess changes in the extent of seagrass beds due to oyster farming is that the area directly beneath the oyster farm structure is obscured in aerial images. This area could also be considered the area where impacts from oyster farming on seagrass are most likely to occur, such as from shading or scour by farm structures. Therefore, in order to effectively determine the effect of oyster aquaculture on seagrass using aerial photographic mapping, complimentary field sampling was used to determine potential impacts of oyster aquaculture on seagrass directly beneath the farming structure.

\section{MATERIALS AND METHODS}

\section{Site location}

The oyster farm is on an intertidal sandbank in the southern arm of the Kaipara Harbour, New Zealand $\left(36^{\circ} 25^{\prime} 41.39^{\prime \prime} \mathrm{S}, 174^{\circ} 18^{\prime} 46.70^{\prime \prime}\right.$ E) (Fig. 1). The sand- 


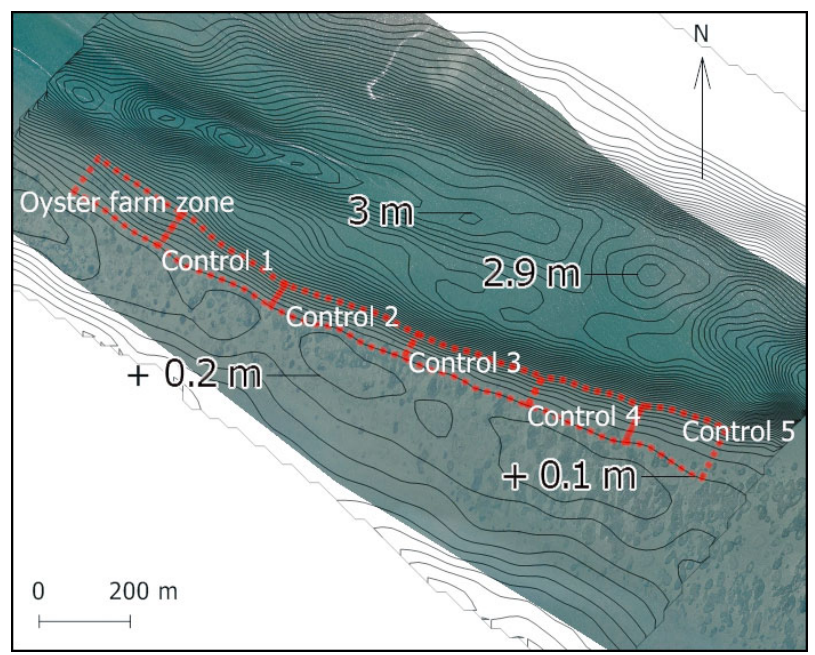

Fig. 1. Aerial photograph taken on 4 June 2010 of the study site within the Kaipara Harbour, New Zealand. Sandbank showing location of oyster farm zone and 5 control zones for analysis in Manifold GIS, with superimposed bathymetry (contour lines every $0.1 \mathrm{~m}$; positive values: above lowest astronomical tide)

bar at its highest point is $0.4 \mathrm{~m}$ above the lowest astronomical tide (LAT) and is adjacent to a harbour channel which runs from southeast to northwest and has a maximum depth of $3.6 \mathrm{~m}$ LAT. The sandbank and the shallower margins of the channel are vegetated with patches of the only seagrass species found in New Zealand waters, Zostera muelleri. The development of the oyster farm began in 2008, and by 2010 the farm covered $\sim 11$ ha in a rectangle running parallel to the channel. The farm uses hanging basket technology for the aquaculture of Pacific oysters Crassostrea gigas, whereby plastic baskets containing Pacific oysters are hung, using clips or hooks, from growout lines of plastic-coated wire stretched between posts driven at $3.2 \mathrm{~m}$ intervals into the seabed (Fig. 2). Five parallel growout lines of wire are spaced $20 \mathrm{~m}$ apart and run perpendicular to the channel and across the sandbank for about $200 \mathrm{~m}$. The farm is serviced from the water by a specialised barge, enabling workers to access baskets without trampling seagrass below.

\section{Area of seabed occupied by seagrass}

Aerial photographs at approximately 1:7000 Ground Sample Distance (GSD) were collected on 3 May 2006, 24 March 2007, 17 March 2008, 24 March 2009, and 4 June 2010 by the oyster farming enterprise (Biomarine Ltd) as part of their environmental monitoring. The photographs had a resolution of $0.1 \mathrm{~m}$ and were taken at low tide during calm water conditions so that seagrass beds were clearly visible. The photographs were then uploaded and georeferenced in Manifold GIS software against known GPS coordinates taken in the field. The oyster farm was constructed between 2008 and 2009, with construction commencing immediately after the 17 March 2008 aerial photograph was taken and completed and operationalised before the 24 March 2009 photograph. Therefore, aerial photographs from 2006 to 2008 and from 2009 and 2010 represented before and after conditions at the study site, respectively.

An oyster farm zone was designated as the area beneath and in between the growout lines of the oyster farm that were within the known depth range for seagrass growth and survival for this region of the Kaipara Harbour (Bulmer 2011) (Fig. 1). The area of the sandbank adjacent and to the southeast of the oyster farm zone with the same depth range was designated as the control zone (Fig. 1). The control zone was further divided into a series of 5 adjacent subzones, each of a similar area to the oyster farm zone, i.e. approximately $19000 \mathrm{~m}^{2}$ (Fig. 1). The outline of all patches of seagrass within the oyster farm zone and each control sub-zone were then carefully traced in Manifold GIS and the total area of seagrass within each zone was calculated. The area directly beneath

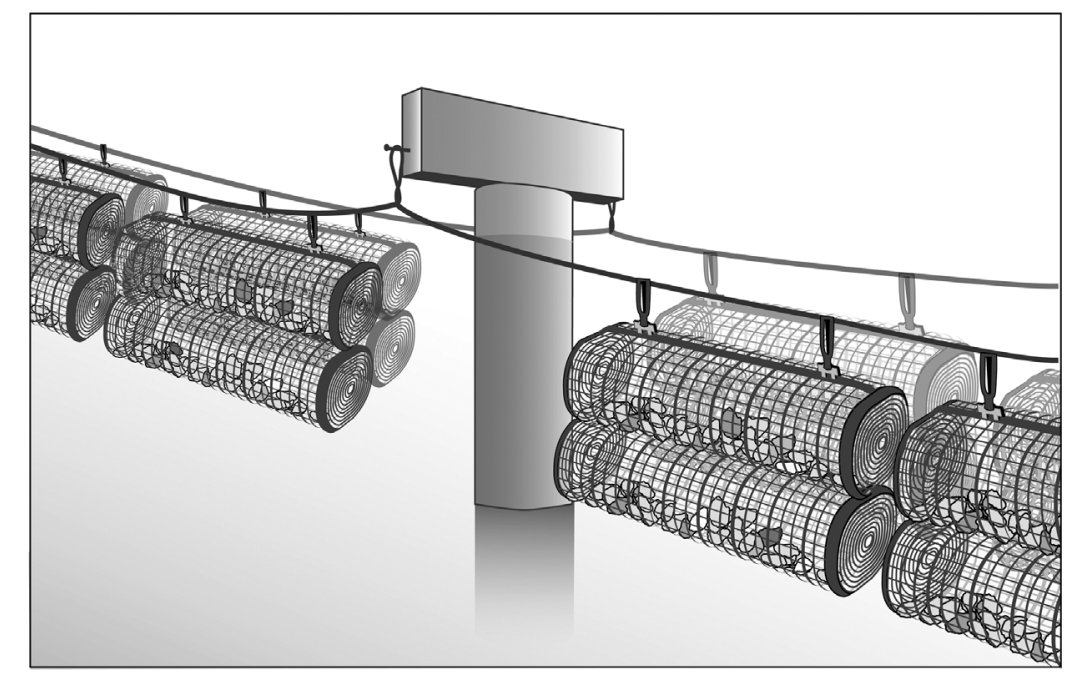

Fig. 2. Schematic setup of hanging basket oyster farming showing the baskets containing Pacific oysters Crassostrea gigas that are attached using clips or hooks from growout lines of plastic-coated wire stretched between posts driven at $3.2 \mathrm{~m}$ intervals into the seabed 
the oyster farm growout lines was not considered in the analyses because the farm structure obscured the seafloor in the aerial photographs which prevented accurate measurement of seagrass coverage for these areas. In total, this area represented less than $5 \%$ of the entire oyster farm zone that was assessed. Seagrass mapping was repeated for each of the 5 aerial photographs of the farm site taken over the $4 \mathrm{yr}$ period. Changes in the total area occupied by seagrass for each zone were measured by comparisons between successive photographs taken each year. Measured changes between subsequent years were calculated as proportions because the growth of seagrass patches is primarily through vegetative propagation (Turner \& Schwarz 2006), and therefore changes in the size of seagrass patches over time are greatly influenced by the initial patch size. Concomitantly, as more of the seabed is occupied by seagrass, it leaves a decreasing amount of unoccupied area potentially available for expansion by seagrass in the following year.

\section{Seagrass directly beneath oyster farm structure}

Field sampling of seagrass was undertaken to determine possible effects of the oyster farm on the cover of seagrass directly beneath the growout lines that was obscured in the aerial photographs. On 14 January 2011 the percentage cover of seagrass was measured at $1 \mathrm{~m}$ intervals along each of the 5 growout lines, i.e. 1000 samples in total. Percentage cover of seagrass was measured by placing a $25 \times$ $25 \mathrm{~cm}$ quadrat directly beneath the growout line, and the percentage cover of seagrass within the quadrat was estimated according to the following 6 categories; $0,0 \leq 5,6-25,26-50$, and $51-75 \%$ of seagrass cover, which were represented as the median values of their percent cover ranges, respectively, i.e. 0, 2.5, $15.5,38,63$, and $88 \%$. In addition, the same sampling methodology was undertaken along the mid-line between each parallel pair of growout lines, i.e. $10 \mathrm{~m}$ from each line.

Cover of seagrass from the quadrat sampling in the field was also compared to further analyses of the set of historical aerial photographs of the farm site. For 2 of the aerial photographs taken prior to the construction of the oyster farm (i.e. 24 March 2007 and 17 March 2008), lines corresponding to the positions of the growout lines were drawn in manifold GIS and then sampled at $1 \mathrm{~m}$ intervals to determine cover of seagrass. The same procedure was repeated along the mid-line between each parallel pair of growout lines for all 5 of the annual aerial photographs.

\section{Data analyses}

Two statistical methods were used for analysing the results. The Friedman repeated measures analysis of ranks was conducted with Sigmaplot software (Systat software) and Pearson's chi-square with SPSS Statistics (version 17.0).

A Friedman repeated measures analysis of ranks was used to detect any significant differences $(\alpha=$ 0.05 ) in the proportional change in area occupied by seagrass among all zones for years 2009 and 2010, following the construction of the oyster farm.

To determine whether the proportions of seagrass cover in the categories measured by the quadrats $(0 \%, 0 \leq 5,6-25,26-50$, and 51-75\%) were different directly beneath oyster farm lines versus in between the growout lines, the quadrat data for each were compared with a Pearson's chi-square test.

Pearson's chi-square goodness-of-fit test was used on the pooled number of points along lines drawn in Manifold GIS positioned equidistant between oyster farm lines 1 to 5 (2010 aerial photograph) with and without seagrass present, and the pooled number of quadrats with seagrass present between Rows 1 to 5 in the 2011 field survey. This analysis was used to detect whether significant differences existed between the proportion of lines with seagrass present in 2010 aerial photograph analysis and the 2011 field sampling. Separate comparisons were conducted between the aerial photographs for the years 2007 and 2008 and the 2011 field data, for the 2 sets of quadrat data from directly beneath and in between the growout lines.

Data from beneath growout line 5 was excluded from all statistical comparisons as the growout line had been damaged and had not been used for farming oysters in the prior 6 mo (approximately) (D. Dollimore, Biomarine Ltd, pers. comm.).

\section{RESULTS AND DISCUSSION}

While detecting changes in seagrass beds over time using aerial and satellite images is not new, this technique has only recently been used to detect impacts of oyster farm aquaculture on seagrass (Barillé et al. 2010, Martin et al. 2010). One of the problems with such an assessment is that oyster farm structures obscure the aerial view of seagrass directly beneath farm structure, where the potential impacts from oyster farm aquaculture on seagrass, such as from shading or scour, could be anticipated to be at their maximum. In the present study we have 
addressed this problem by directly measuring the distribution of seagrass Zostera muelleri directly beneath oyster farm structures by field sampling in addition to analysing aerial photographs to determine the impact of hanging basket oyster aquaculture technology on seagrass.

\section{Area of seabed occupied by seagrass}

The total area covered by seagrass within the oyster farm zone increased between the consecutive aerial photographs from 2006 to 2010 (Table 1). In the 2008 photograph immediately prior to the oyster farm construction, seagrass occupied $610 \mathrm{~m}^{2}(3.1 \%)$ of the total area of the oyster farm zone, and in the 2010 photograph after the farm had been in operation for over a year, seagrass had expanded to occupy a total of $2537 \mathrm{~m}^{2}(12.8 \%)$ of the zone. The total seagrass cover in all 5 control zones also increased over this period (Table 1).

Of all the 6 measured zones, control zone 2 contained the largest total area of seagrass in all years, ranging from $8640 \mathrm{~m}^{2}$ in 2006 to $7033 \mathrm{~m}^{2}$ in 2010 , or 43.4 to $35.3 \%$ of the total area of the zone, respectively. In comparison, seagrass cover in the oyster farm zone ranged from $24 \mathrm{~m}^{2}$ in 2006 to $2537 \mathrm{~m}^{2}$ in 2010 , or 0.1 to $12.8 \%$, respectively of the total area of the oyster farm zone (Table 1).

Prior to the oyster farm being constructed, there was a considerable increase in seagrass cover within the oyster farm zone from 2006 to 2007 (20.1 times the total seagrass cover) while all the other control zones contracted ( 0.3 to 0.9 times the total seagrass cover). From 2007 to 2008 the increase in seagrass cover within the oyster farm zone (1.3 times the total seagrass cover) was comparable with the control zones (which ranged from 0.9 to 1.1 times the total seagrass cover). There was an increase ranging from 0.9 to 2.4 times the total seagrass cover in each of the 6 zones from 2008 (aerial photograph taken immediately prior to the construction of the oyster farm) to 2010 (farm had been in place for over a year). No significant difference was detected among the proportional change in total seagrass cover in all zones from 2008 to 2009 and 2009 to $2010\left(\chi^{2}=10, \mathrm{df}=5\right.$, p >0.05; Table 1) following the development of the oyster farm.

These results are consistent with other studies that have investigated the impact of oyster farming on seagrass beds using remote sensing methods. For example, analyses of satellite images and aerial photographs of seagrass beds in France found that there
Table 1. Zostera muelleri. Changes in total cover of seagrass within the oyster farm zone and 5 control zones as assessed from aerial photographs. Annual change: proportional change, i.e. total seagrass cover $\left(\mathrm{m}^{2}\right)$ devided by previous year's total seagrass cover $\left(\mathrm{m}^{2}\right)$. Percent cover: total cover of seagrass as \% of total available zone area

\begin{tabular}{|c|c|c|c|c|}
\hline Zone (area) & Year & $\begin{array}{c}\text { Seagrass } \\
\left(\mathrm{m}^{2}\right)\end{array}$ & $\begin{array}{l}\text { S cover } \\
(\%)\end{array}$ & $\begin{array}{l}\text { Annual } \\
\text { change }\end{array}$ \\
\hline \multicolumn{5}{|c|}{ Oyster farm (19799 m²) } \\
\hline \multirow[t]{3}{*}{ Pre-farming } & 2006 & 23.5 & 0.1 & \\
\hline & 2007 & 473 & 2.4 & 20.1 \\
\hline & 2008 & 610 & 3.1 & 1.3 \\
\hline \multirow[t]{2}{*}{ Post-farming } & 2009 & 1285 & 6.5 & 2.1 \\
\hline & 2010 & 2537 & 12.8 & 2.0 \\
\hline \multicolumn{5}{|l|}{ Control 1 (19602 m²) } \\
\hline \multirow{3}{*}{ Pre-farming } & 2006 & 1583 & 8.1 & \\
\hline & 2007 & 498 & 2.5 & 0.3 \\
\hline & 2008 & 530 & 2.7 & 1.1 \\
\hline \multirow[t]{2}{*}{ Post-farming } & 2009 & 1200 & 6.1 & 2.3 \\
\hline & 2010 & 2914 & 14.9 & 2.4 \\
\hline \multicolumn{5}{|l|}{ Control $2\left(19923 \mathrm{~m}^{2}\right)$} \\
\hline \multirow[t]{3}{*}{ Pre-farming } & 2006 & 8640 & 43.4 & \\
\hline & 2007 & 5496 & 27.6 & 0.6 \\
\hline & 2008 & 5202 & 26.1 & 1.0 \\
\hline \multirow[t]{2}{*}{ Post-farming } & 2009 & 5519 & 27.7 & 1.1 \\
\hline & 2010 & 7033 & 35.3 & 1.3 \\
\hline \multicolumn{5}{|l|}{ Control 3 (19 $\left.019 \mathrm{~m}^{2}\right)$} \\
\hline \multirow[t]{3}{*}{ Pre-farming } & 2006 & 1972 & 10.4 & \\
\hline & 2007 & 717 & 3.8 & 0.4 \\
\hline & 2008 & 640 & 3.4 & 0.9 \\
\hline \multirow[t]{2}{*}{ Post-farming } & 2009 & 923 & 4.9 & 1.4 \\
\hline & 2010 & 1786 & 9.4 & 1.9 \\
\hline \multicolumn{5}{|l|}{ Control $4\left(19425 \mathrm{~m}^{2}\right)$} \\
\hline \multirow[t]{3}{*}{ Pre-farming } & 2006 & 2434 & 12.5 & \\
\hline & 2007 & 1645 & 8.5 & 0.7 \\
\hline & 2008 & 1759 & 9.1 & 1.1 \\
\hline \multirow[t]{2}{*}{ Post-farming } & 2009 & 2070 & 10.7 & 1.2 \\
\hline & 2010 & 2893 & 14.9 & 1.4 \\
\hline \multicolumn{5}{|l|}{ Control 5 (19838 m²) } \\
\hline \multirow[t]{3}{*}{ Pre-farming } & 2006 & 1174 & 5.9 & \\
\hline & 2007 & 1009 & 5.1 & 0.9 \\
\hline & 2008 & 1075 & 5.4 & 1.1 \\
\hline \multirow[t]{2}{*}{ Post-farming } & 2009 & 1531 & 7.7 & 1.4 \\
\hline & 2010 & 2503 & 12.6 & 1.6 \\
\hline
\end{tabular}

was no impact of Pacific oyster Crassostrea gigas farms (both traditional and hanging basket technologies) on the adjacent area of seagrass (Zostera noltii and Zostera marina) (Barillé et al. 2010, Martin et al. 2010). However, neither study examined the area directly beneath oyster farm structures which is obscured when using overhead remote sensing methods. This is a major drawback of the validity of these techniques because potential impacts, such as 
shading or scour caused by oyster farm structures, may be anticipated to be at their maximum within this area, and therefore associated effects on seagrass are most likely to be detected in this area.

\section{Seagrass directly beneath oyster farm structure}

As the effect on seagrass directly beneath oyster farm structures was not detectable in aerial photographs, field sampling of the farm site was conducted. The sampling showed that seagrass is capable of growing directly beneath hanging basket oyster farm structures, with seagrass present in an average of $11.2 \% \pm 3.87 \mathrm{SE}$ of the quadrats sampled directly beneath oyster farm growout lines (Fig. 3). In contrast, seagrass was present in significantly more quadrats in between oyster farm lines (mean $\pm \mathrm{SE}, 31 \pm 9.65 \%$; $\chi^{2}=82.97$, df $=1, \mathrm{p}<0.01$; Fig. 3). In addition, the mean percent cover of seagrass growing directly beneath oyster farm lines was found to be significantly less than that of seagrass found growing in between lines $(1.27 \pm 0.15 \%$ compared to $6.5 \pm 0.32 \%$, respectively; $\chi^{2}=101.32$, df $=4, \mathrm{p}<0.01$; Fig. 4).

In a comparable study investigating the impact of hanging basket oyster farming on seagrass in Murat Bay, Australia, no detectable difference among seagrass (Posidonia australis) biomass directly beneath and in between oyster farm growout lines and at control sites outside of the farm were detected (Madigan et al. 2000). Similar findings were documented in a

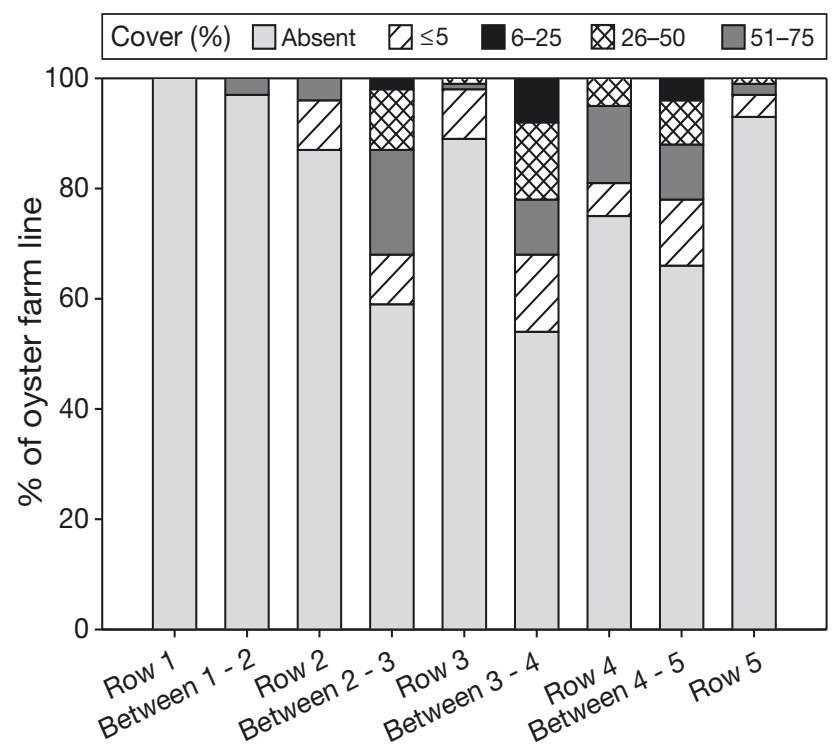

Fig. 3. Percent cover of seagrass present beneath and in between oyster farm lines (absent $=0, \leq 5,6-25,26-50$, and $51-75 \%$ seagrass cover) as percentage of each transect line study investigating the effects of hanging basket subtidal oyster (Crassostrea gigas) farming on the benthic environment in Tasmania, Australia, with analyses of video transects directly beneath oyster farm structure suggesting that the impact on 2 species of seagrasses (Heterozostera tasmanica and Halophila australis) was minimal (Crawford et al. 2003).

In comparison, in the present study in the Kaipara Harbour, the overall proportion of the area directly beneath the oyster farm structure occupied by seagrass in 2011 as assessed by field sampling (seagrass present in 98 out of 800 quadrats) was found to be significantly higher than in 2008, as assessed by analysis of aerial photographs (seagrass present in 24 out of 800 quadrats; $\chi^{2}=48.59, \mathrm{df}=1, \mathrm{p}<0.01$; Fig. 5). A significant increase in total area occupied by seagrass from 2008 to 2011 was also measured for the area in between oyster farm growout lines by using analysis of aerial photographs and field sampling methods (seagrass present in 27 out of 800 quadrats in 2008, and 248 out of 800 quadrats in 2011; $\chi^{2}=214.47$, df $=$ $1, \mathrm{p}<0.01$; Fig. 5). Together these results suggest that the extent of seagrass increased both directly beneath and in between oyster farm growout lines following farm construction in 2008-2009, and this was consistent with a longer term trend over 5 yr for increasing seagrass in this area, including the areas of seabed outside the farm that were monitored.

In the present study it appears that hanging basket oyster aquaculture technology has not resulted in a reduction in the overall area of seagrass beneath the farm; however, it is possible that the observed areawide increases in seagrass have been impaired in the narrow band directly beneath oyster farm lines. For

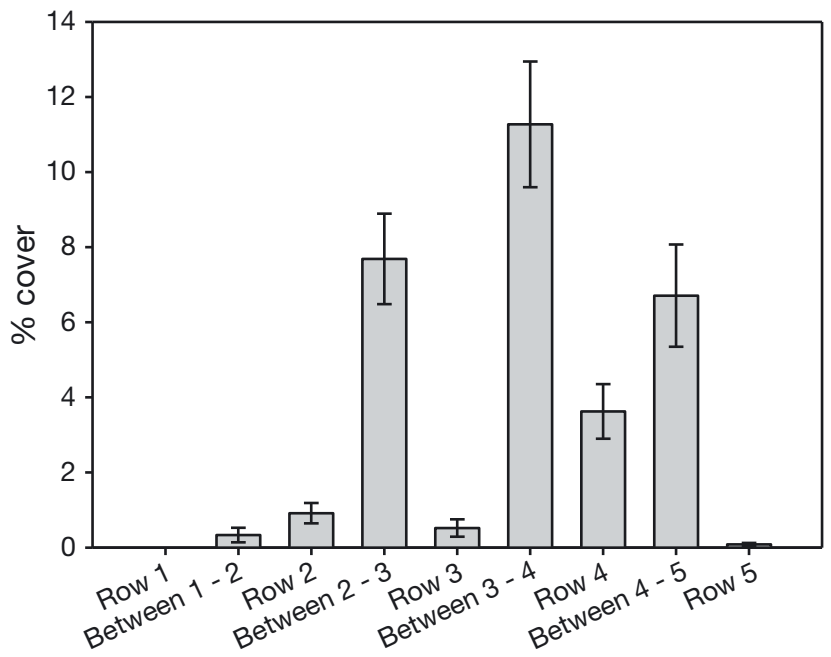

Fig. 4. Mean $( \pm \mathrm{SE})$ percent cover of seagrass directly beneath and in between oyster farm growout lines 


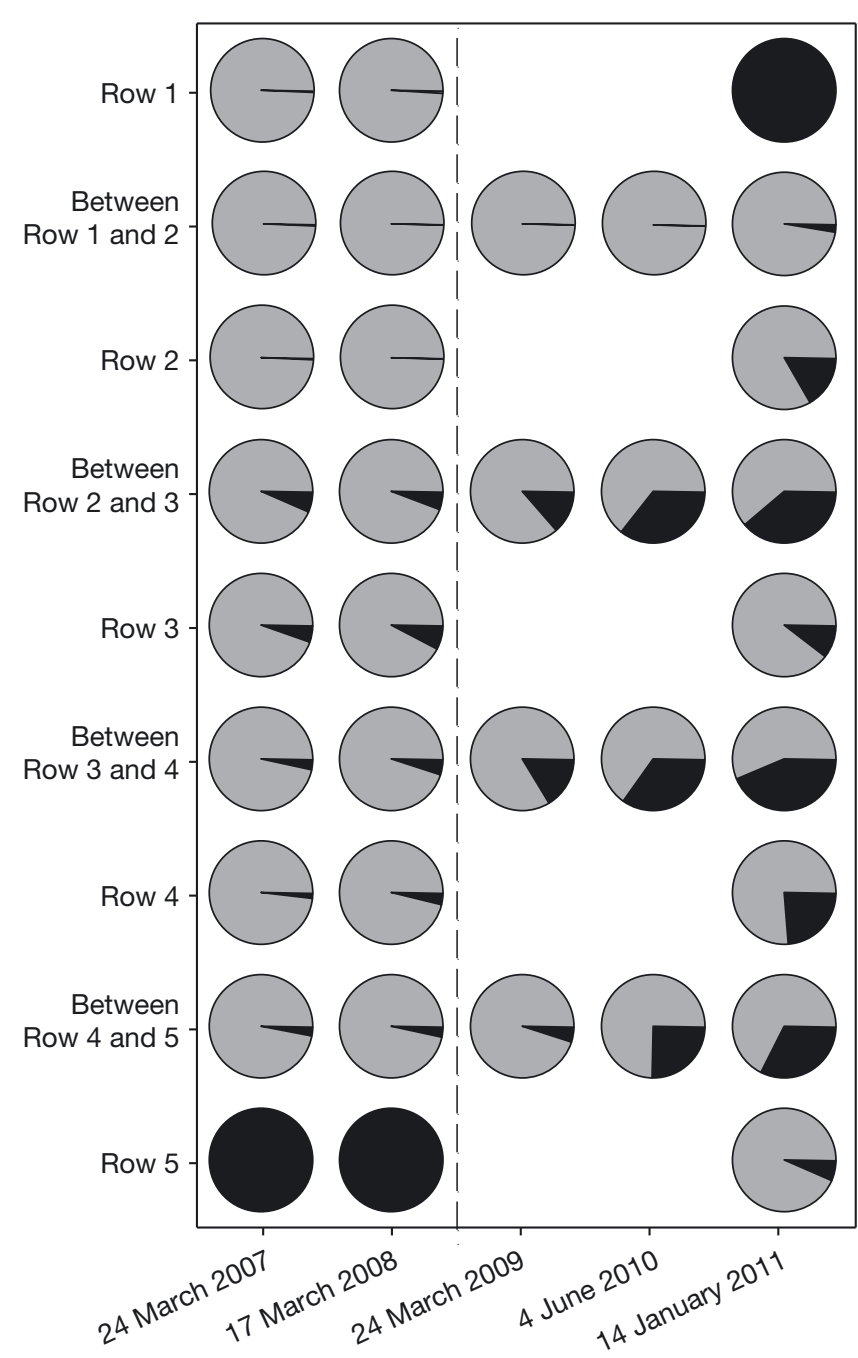

Fig. 5. Percentages of sampling locations beneath oyster farm growout lines (1-5) and in between oyster farm growout lines with seagrass present (shaded black) and absent (shaded grey) as measured from aerial photographs and field sampling from 2007 to 2011. Dashed vertical line: installation of farm

example, in 2008 when the oyster farm was being developed, the number of samples with seagrass present was not different beneath and in between oyster farm growout lines (seagrass present in 24 out of 800 quadrats beneath lines, and 27 out of 800 in between lines). However, by 2011 significantly more samples had seagrass present in between oyster farm lines (248 out of 800) than beneath oyster farm lines (98 out of 800$)\left(\chi^{2}=82.97, \mathrm{df}=1, \mathrm{p}<0.01\right)$.

It is possible that favourable environmental conditions from the time the oyster farm was established, such as relatively mild weather patterns, resulted in the trend of seagrass patch expansion throughout the farm and the control zones observed in this study.
Seagrasses have been shown to be susceptible to reduced light associated with pulsed turbidity events, such as flooding, and seasonal variation in light availability (Longstaff \& Dennison 1999). During periods when light availability is limited, further reduction due to shading by oyster farm structure may result in greater impacts on seagrass than that observed in the present study. Seasonal differences in seagrass patch expansion or contraction may also explain some of the difference observed in seagrass cover among aerial photographs and between aerial photographs and field survey results.

\section{CONCLUSIONS}

This study shows that hanging basket oyster farm technology has no impact on seagrass distribution, other than in a narrow band directly beneath the oyster farm structure, which represents less than $5 \%$ of the total farm area. These minimal impacts on seagrass were probably due to shading or scour caused by oyster farm structures. Remote sensing was found to be a useful tool for examining the potential impact of the aquaculture activity on the seagrass, especially when used in combination with field sampling to examine those areas obscured by farm structures.

Acknowledgements. This research was supported by the Foundation for Research, Science and Technology in New Zealand, the Glenn Family Foundation, and Biomarine Ltd. The authors are grateful to the support staff at the Leigh Marine Laboratory University of Auckland for their assistance.

\section{LITERATURE CITED}

Abal EG, Loneragan N, Bowen P, Perry CJ, Udy JW, Dennison WC (1994) Physiological and morphological responses of the seagrass Zostera capricorni Aschers, to light intensity. J Exp Mar Biol Ecol 178:113-129

Barillé L, Robin M, Harin N, Bargain A, Launeau P (2010) Increase in seagrass distribution at Bourgneuf Bay (France) detected by spatial remote sensing. Aquat Bot 92:185-194

Bité J, Campbell S, Mckenzie L, Coles R (2007) Chlorophyll fluorescence measures of seagrasses Halophila ovalis and Zostera capricorni reveal differences in response to experimental shading. Mar Biol 152:405-414

Bulmer R (2011) The impact of shading by oyster farm structure on seagrass, Zostera muelleri, in the Kaipara Harbour. MSc thesis, Marine Science, University of Auckland

Cocheret de la Morinière E, Pollux BJA, Nagelkerken I, Van Der Velde G (2002) Post-settlement life cycle migration patterns and habitat preference of coral reef fish that use seagrass and mangrove habitats as nurseries. Estuar Coast Shelf Sci 55:309-321

Collier CJ, Lavery PS, Ralph PJ, Masini RJ (2009) Shade- 
induced response and recovery of the seagrass Posidonia sinuosa. J Exp Mar Biol Ecol 370:89-103

Costanza R, D'Arge R, De Groot R, Fraber S and others (1997) The value of theworld's ecosystem services and natural capital. Nature 387:253-260

Crawford CM, Macleod CKA, Mitchell IM (2003) Effects of shellfish farming on the benthic environment. Aquaculture 224:117-140

Czerny AB, Dunton K (1995) The effects of in situ light reduction on the growth of two subtropical seagrasses, Thalassia testudinum and Halodule wrightii. Estuaries 18:418-427

Everett RA, Ruiz GM, Carlton JT (1995) Effect of oyster mariculture on submerged aquatic vegetation: an experimental test in a Pacific Northwest estuary. Mar Ecol Prog Ser 125:205-217

Forrest BM, Keeley NB, Hopkins GA, Webb SC, Clement DM (2009) Bivalve aquaculture in estuaries: review and synthesis of oyster cultivation effects. Aquaculture 298:1-15

Kendrick GA, Aylward MJ, Hegge BJ, Cambridge ML, Hillman K, Wyllie A, Lord DA (2002) Changes in seagrass coverage in Cockburn Sound, Western Australia between 1967 and 1999. Aquat Bot 73:75-87

Lathrop RG, Montesano P, Haag S (2006) A multi-scale segmentation approach to mapping seagrass habitats using airborne digital camera imagery. Photogramm Eng Remote Sensing 72:665-675

Longstaff BJ (2003) Investigations into the light requirements of seagrasses in northeast Australia. PhD thesis, University of Queensland, Brisbane

Longstaff BJ, Dennison WC (1999) Seagrass survival during pulsed turbidity events: the effects of light deprivation on the seagrasses Halodule pinifolia and Halophila ovalis. Aquat Bot 65:105-121

Editorial responsibility: Marianne Holmer, Odense, Denmark
Madigan S, Venema S, Haskard K, Clarke S (2000) Oyster Environmental Monitoring Program (OEMP): small-scale seagrass health study. South Australian Research and Development Institute (Aquatic Sciences), Adelaide

Martin P, Sébastien D, Gilles T, Isabelle A and others (2010) Long-term evolution (1988-2008) of Zostera spp. meadows in Arcachon Bay (Bay of Biscay). Estuar Coast Shelf Sci 87:357-366

Morrison MA, Lowe ML, Parsons DM, Usmar NR, McLeod IM (2009) A review of land-based effects on coastal fisheries and supporting biodiversity in New Zealand. New Zealand Aquatic Environment and Biodiversity Report 37, Ministry of Fisheries, Wellington

Nagelkerken I, Kleijnen S, Klop T, van den Brand RACJ, Cocheret de la Morinière E, van der Velde G (2001) Dependence of Caribbean reef fishes on mangroves and seagrass beds as nursery habitats: a comparison of fish faunas between bays with and without mangroves/seagrass beds. Mar Ecol Prog Ser 214:225-235

> Orth RJ, Luckenbach ML, Marion SR, Moore KA, Wilcox DJ (2006) Seagrass recovery in the Delmarva Coastal Bays, USA. Aquat Bot 84:26-36

Turner S, Schwarz AM (2006) Management and conservation of seagrass in New Zealand: an introduction. In: O'Leary H (ed) Science for conservation, Vol 264. Science \& Technical Publishing, Dept of Conservation, Wellington

Young PC, Kirkman H (1975) The seagrass communities of Moreton Bay, Queensland. Aquat Bot 1:191-202

> Zharikov Y, Skilleter GA, Loneragan NR, Taranto T, Cameron BE (2005) Mapping and characterising subtropical estuarine landscapes using aerial photography and GIS for potential application in wildlife conservation and management. Biol Conserv 125:87-100

Submitted: January 30, 2012; Accepted: August 6, 2012 Proofs received from author(s): September 9, 2012 